Article

\title{
Bioactive Hydantoin Alkaloids from the Red Sea Marine Sponge Hemimycale arabica
}

\section{Diaa T. A. Youssef ${ }^{1, *}$, Lamiaa A. Shaala ${ }^{2,3}$ and Khalid Z. Alshali ${ }^{4}$}

1 Department of Natural Products, Faculty of Pharmacy, King Abdulaziz University, Jeddah 21589, Saudi Arabia

2 Natural Products Unit, King Fahd Medical Research Center, King Abdulaziz University, Jeddah 21589, Saudi Arabia; E-Mail: 1shalla@kau.edu.sa

3 Suez Canal University Hospital, Suez Canal University, Ismailia 41522, Egypt

4 Department of Medicine, Faculty of Medicine, King Abdulaziz University, Jeddah 21589 , Saudi Arabia; E-Mail:kalshali@kau.edu.sa orkzalshal@yahoo.com

* Author to whom correspondence should be addressed; E-Mail: dyoussef@kau.edu.sa; Tel.: +966-548-535-344; Fax: +966-269-516-96.

Academic Editor: Vassilios Roussis

Received: 13 September 2015 / Accepted: 26 October 2015 / Published: 28 October 2015

\begin{abstract}
In the course of our continuing efforts to identify bioactive secondary metabolites from Red Sea marine invertebrates, we have investigated the sponge Hemimycale arabica. The antimicrobial fraction of an organic extract of the sponge afforded two new hydantoin alkaloids, hemimycalins A and B (2 and 3), together with the previously reported compound (Z)-5-(4-hydroxybenzylidene)imidazolidine-2,4-dione (1). The structures of the compounds were determined by extensive 1D and 2D NMR (COSY, HSQC and HMBC) studies and high-resolution mass spectral determinations. Hemimycalins A (2) and B (3) represent the first examples of the natural $N$-alkylated hydantoins from the sponge Hemimycale arabica. Compounds 1-3 displayed variable antimicrobial activities against $E$. coli, $S$. aureus, and $C$. albicans. In addition, compound 1 displayed moderate antiproliferative activity against the human cervical carcinoma (HeLa) cell line. These findings provide further insight into the chemical diversity as well as the biological activity of this class of compounds.
\end{abstract}

Keywords: Red Sea sponge; Hemimycale arabica; $\mathrm{N}$-alkylated hydantoins; hemimycalins $\mathrm{A}$ and $\mathrm{B}$; antimicrobial and antiproliferative activities; HeLa cells 


\section{Introduction}

The marine environment has proven to be a very rich source of extremely potent compounds with significant activities including antitumor, anti-inflammatory, analgesic, immunomodulatory, anti-allergic, and anti-viral [1]. Bioactive natural products have been isolated from marine macro- or micro-organisms. To date, about 24,662 new compounds have been reported from marine organisms since 1963 [2]. Marine sponges (phylum Porifera) are among the oldest multicellular invertebrate organisms [3], exhibiting a wide variety of colors and shapes. To date, about 11,000 species have been formally described, of which approximately 8500 are considered valid [4]. Marine sponges continue to attract wide attention from marine natural product chemists and pharmacologists alike due to their remarkable diversity of bioactive compounds [5,6]. A total of 10 invertebrate-derived compounds are currently in advanced phases of clinical trials [6]. This fact clearly demonstrates and reflects the importance of marine sponges as a potential source for future drug discovery and development [6]. Members of the genus Hemimycale are producers of bioactive secondary metabolites including the complex guanidine alkaloids [7,8] and hydantoin derivatives [9]. Examples of these compounds include ptilomycalin A. It possesses the unique polycyclic guanidine moiety connected with a $\omega$-hydroxyhexadecanoyl-spermidine group through an ester linkage [7,8]. This guanidine alkaloid showed remarkable antifungal, antiviral, and antitumor activities [7,8].

Hydantoin (1,3-imidazolidinedione) derivatives display diverse and interesting pharmacological properties. Several such derivatives (phenytoin, mephenythoin, norantoin, methetoin, ethotoin, fosphenytoin) are well-known anticonvulsive drugs [9,10]. Other 5-substituted hydantoins like 5,5-dithienylhydantoin, 5,5-dipyridylhydantoin, spirothiohydantoin, thiohydantoin, and dithiohydantoins also possess anticonvulsive activity [11,12]. Hydantoin derivatives can also be found as antiarrhythmics (azimilide), antimicrobial agents (nitrofurantoin), skeletal muscle relaxants (dantrolene), and nonsteroidal antiandrogens (nilutamide), while allantoin is used as a keratolytic, astringent, wound remedy, antacid, and antipsoriatic drug [10]. Hydantoins also exhibit antidepressant, antiviral, and antithrombotic activities, as well as inhibitory activity against some enzymes (human aldose reductase and human leucocyte elastase) [13]. Finally, some herbicides (spirohydantoin, thioxohydantocidin), fungicides (clodantoin), and insecticides also have the hydantoin skeleton in their structure $[14,15]$. Some spirohydantoins are considered to be a novel aldose reductase inhibitor to treat diabetes [16].

The natural (Z)-5-(4-hydroxybenzylidene) imidazolidine-2,4-dione (1) and its synthetic derivative (Z)-5-(4-(ethylthio)benzylidene)-hydantoin showed potent in vitro anti-growth and anti-invasive properties against PC-3M prostate cancer cells in MTT and spheroid disaggregation [17]. They decreased the orthotopic tumor growth and inhibited the formation of tumor micrometastases in distant organs without apparent cytotoxic effects at the test doses [17].

In the course of our ongoing search for bioactive compounds from Red Sea marine sponges, we have investigated the antimicrobial fraction of an organic extract of the Red Sea sponge Hemimycale arabica. The study resulted in the identification of three hydantoin alkaloids including two new compounds, hemimycalyins A and B (2 and 3), and the previously reported compound (Z)-5-(4-hydroxybenzylidene) imidazolidine-2,4-dione (1) [18,19]. In this paper, the purification, 
structure determination of compounds $\mathbf{1}-\mathbf{3}$ as well as the antimicrobial and antiproliferative activities of the compounds will be discussed.

\section{Results and Discussion}

\subsection{Purification of Compounds 1-3}

Chromatographic investigation of the organic extract of the Red Sea sponge Hemimycale arabica afforded two new $N$-alkylated hydantoin derivatives, hemimycalins A and B (2 and 3), together the previously reported (Z)-5-(4-hydroxybenzylidene)-imidazolidine-2,4-dione (1). The compounds showed variable antiproliferative and antimicrobial activities.

\subsection{Structure Elucidation of Compound 1-3}

Compound 1 (Figure 1) was purified as yellow amorphous solid. Its molecular formula $\mathrm{C}_{10} \mathrm{H}_{8} \mathrm{~N}_{2} \mathrm{O}_{3}$ was deduced from the positive HRESIMS (high-resolution electrospray ionisation mass spectrometry) pseudomolecular ion peak at $m / z 227.0435[\mathrm{M}+\mathrm{Na}]^{+}$. The structure of 1 was assigned as (Z)-5-(4-hydroxybenzylidene)-imidazolidine-2,4-dione [18,19] based on complete analysis of its NMR data (Table 1) and by comparison to literature data $[18,19]$.

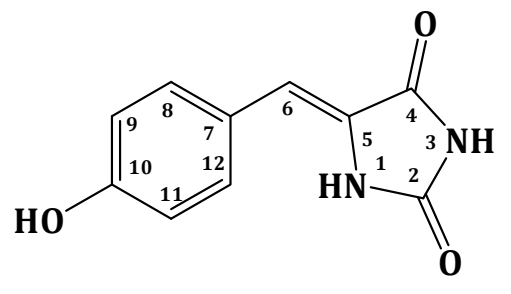

1

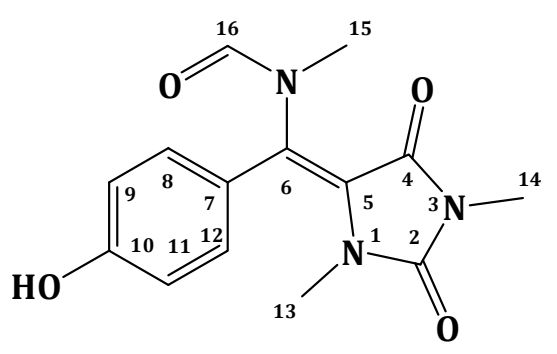

2<smiles>CC(=O)CC(C)N1C(=O)N/C(=C\c2ccc(O)cc2)C1=O</smiles>

3

Figure 1. Structures of compounds 1-3.

Table 1. NMR data and HMBC correlations of compound 1 (DMSO- $d 6$ ).

\begin{tabular}{cccc}
\hline Position & $\boldsymbol{\delta}_{\mathbf{C}}$ & $\boldsymbol{\delta}_{\mathbf{H}}(\mathbf{m}, \boldsymbol{J}$ in $\mathbf{H z})$ & $\mathbf{H M B C}(\mathbf{H} \rightarrow \mathbf{C})^{\mathbf{a}}$ \\
\hline 2 & $155.7, \mathrm{qC}$ & & \\
4 & $165.7, \mathrm{qC}$ & & $\mathrm{H}-6$ \\
5 & $125.3, \mathrm{qC}$ & & \\
6 & $109.2, \mathrm{CH}$ & $6.33(\mathrm{~s})$ & $\mathrm{H}-8, \mathrm{H}-12$ \\
7 & $123.8, \mathrm{qC}$ & & $\mathrm{H}-9, \mathrm{H}-11$ \\
\hline
\end{tabular}


Table 1. Cont.

\begin{tabular}{cccc}
\hline 8 & $131.2, \mathrm{CH}$ & $7.46(\mathrm{~d}, 9.0)$ & $\mathrm{H}-6$ \\
9 & $115.6, \mathrm{CH}$ & $6.76(\mathrm{~d}, 9.0)$ & \\
10 & $158.0, \mathrm{qC}$ & & $\mathrm{H}-8, \mathrm{H}-9, \mathrm{H}-11, \mathrm{H}-12$ \\
11 & $115.6, \mathrm{CH}$ & $6.76(\mathrm{~d}, 9.0)$ & $\mathrm{H}-6$ \\
12 & $131.2, \mathrm{CH}$ & $7.46(\mathrm{~d}, 9.0)$ & \\
$\mathrm{N} H, \mathrm{OH}$ & & $10.0-10.5($ br s $)$ & \\
\hline
\end{tabular}

${ }^{\text {a }} \mathrm{HMBC}$ correlations are from proton(s) stated to the indicated carbons.

Compound 2 (Figure 1) was purified as a yellow amorphous solid with the molecular formula $\mathrm{C}_{14} \mathrm{H}_{15} \mathrm{~N}_{3} \mathrm{O}_{4}$, as established from the HRESIMS pseudomolecular ion peak at $m / z 312.0961[\mathrm{M}+\mathrm{Na}]^{+}$, suggesting nine degrees of unsaturation. The ${ }^{1} \mathrm{H}$ and ${ }^{13} \mathrm{C}$ NMR data of compound $\mathbf{2}$ (Table 2) showed a similarity to those of 1 (Table 1) with additional signals for two $N$-methyls [20-22] and an $N$-methylfromamide moiety $[23,24]$. The signals at $\delta_{H} / \delta_{C} 2.77 / 31.2,3.23 / 29.3$, and $2.80 / 33.5$ were assigned as $\mathrm{H}-13 / \mathrm{C}-13, \mathrm{H}-14 / \mathrm{C}-14$, and $\mathrm{H}-15 / \mathrm{C}-15$, respectively. The downfield NMR signals at $\delta_{\mathrm{H}} / \delta_{\mathrm{C}}$ 7.98 (s)/166.1 are characteristic for a formamide methine [23,24]. Furthermore, the ${ }^{1} \mathrm{H}-{ }^{1} \mathrm{H}$ COSY spectrum supported the $p$-substituted phenyl ring. The location of $N$-methyl groups at $N-1$ and $N-3$ was established from HMBC correlations. HMBC cross-peaks (Figure 2) of H-13/C-2, H-14/C-2 ( $\delta_{\mathrm{C}} 153.4$ ), and $\mathrm{H}-14 / \mathrm{C}-4\left(\delta_{\mathrm{C}} 149.9\right)$ supported the location of these $N$-methyl groups. Furthermore, the location of the $N$-methylformamide moiety at C-6 was secured from HMBC correlations of H-15/C-6 ( $\left.\delta_{\mathrm{C}} 126.0\right)$ H-15/C-5 ( $\left.\delta_{C} 93.8\right), H-15 / C-16\left(\delta_{C} 166.1\right)$, and H-16/C-15 ( $\left.\delta_{C} 33.5\right)$ (Figures 1 and 2). Finally, the chemical shift values of the para-substituted benzene ring were in good agreement with those of $\mathbf{1}$ (Table 1). From the above discussion, compound $\mathbf{2}$ was assigned as $N-((E)$-(4-hydroxyphenyl) (1,3-dimethyl-2,5-dioxoimidazolidin-4-ylidene)methyl)- $N$-methylformamide (Figures 1 and 2$)$. To the best of our knowledge, compound $\mathbf{2}$ is reported here for the first time from a natural source and is considered as a new compound. The generic name hemimycalin A was given to 2 .

Table 2. NMR data and HMBC correlations of compound 2 (DMSO- $d_{6}$ ).

\begin{tabular}{cccc}
\hline Position & $\boldsymbol{\delta}_{\mathbf{C}}$ & $\boldsymbol{\delta}_{\mathbf{H}}(\mathbf{m}, \boldsymbol{J}$ in $\mathbf{H z})$ & $\mathbf{H M B C}(\mathbf{H} \rightarrow \mathbf{C})^{\mathbf{a}}$ \\
\hline 2 & $153.4, \mathrm{qC}$ & & $\mathrm{H}_{3}-13, \mathrm{H}_{3}-14$ \\
4 & $149.9, \mathrm{qC}$ & & $\mathrm{H}_{3}-14$ \\
5 & $93.8, \mathrm{qC}$ & & $\mathrm{H}_{3}-13$ \\
6 & $126.0, \mathrm{qC}$ & & $\mathrm{H}-8, \mathrm{H}-12, \mathrm{H}_{3}-15$ \\
7 & $124.6, \mathrm{qC}$ & & $\mathrm{H}-9, \mathrm{H}-11$ \\
8 & $131.1, \mathrm{CH}$ & $7.44(\mathrm{~d}, 8.4)$ & \\
9 & $115.6, \mathrm{CH}$ & $6.75(\mathrm{~d}, 8.4)$ & $\mathrm{H}-8, \mathrm{H}-9, \mathrm{H}-11, \mathrm{H}-12$ \\
10 & $159.4, \mathrm{qC}$ & & \\
11 & $115.6, \mathrm{CH}$ & $6.75(\mathrm{~d}, 8.4)$ & \\
12 & $131.1, \mathrm{CH}$ & $7.44(\mathrm{~d}, 8.4)$ & \\
13 & $31.2, \mathrm{CH}$ & $2.77(\mathrm{~s})$ & $\mathrm{H}-16$ \\
14 & $29.3, \mathrm{CH}$ & $3.23(\mathrm{~s})$ & $\mathrm{H}-15$ \\
15 & $33.5, \mathrm{CH}$ & $2.80(\mathrm{~s})$ & \\
16 & $166.1, \mathrm{CH}$ & $7.89(\mathrm{~s})$ & \\
$\mathrm{OH}$ & & $10.88(\mathrm{br} \mathrm{s})$ & \\
\hline
\end{tabular}

${ }^{\mathrm{a}} \mathrm{HMBC}$ correlations are from proton(s) stated to the indicated carbons. 


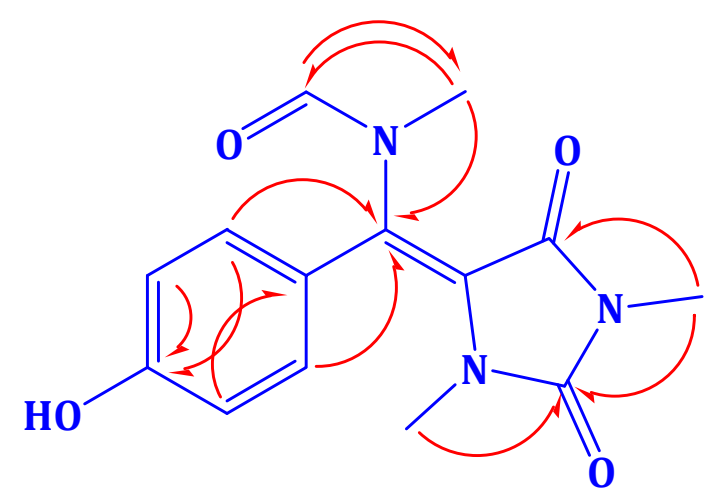

2

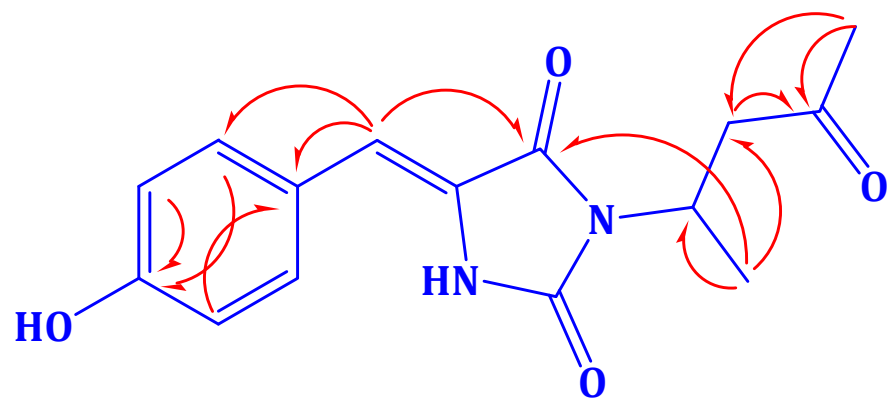

3

Figure 2. Selected HMBC correlations of compounds $\mathbf{2}$ and $\mathbf{3}$.

Compound 3 (Figure 1) showed the molecular formula $\mathrm{C}_{15} \mathrm{H}_{16} \mathrm{~N}_{2} \mathrm{O}_{4}$, as established from the pseudomolecular ion peak at $m / z 311.1009$ for $[\mathrm{M}+\mathrm{Na}]^{+}$, requiring nine degrees of unsaturation. The NMR spectra of $\mathbf{3}$ (Table 3) showed a close similarity to those of $\mathbf{1}$ (Table 1). Additional signals for the 4-aminopentan-2-one moiety were observed. This was evident for the ${ }^{1} \mathrm{H}-{ }^{1} \mathrm{H}$ COSY non-interrupted spin-coupling system from $\mathrm{H}_{3}-17\left(\delta_{\mathrm{H}} 1.36, J=7.2 \mathrm{~Hz}\right)$ to $\mathrm{H}-13\left(\delta_{\mathrm{H}} 4.64, \mathrm{~m}\right)$ which further couples with $\mathrm{H}_{2}-14\left(\delta_{\mathrm{H}} 3.35\right.$ and 3.00) (Table 3). A three-proton singlet at $\delta_{\mathrm{H}} 2.12\left(\mathrm{H}_{3}-16\right)$ together with the ${ }^{13} \mathrm{C}$ NMR signal at $\delta_{\mathrm{C}} 208.6$ (qC, C-15) are characteristic for a terminal methyl ketone moiety. The HMBC correlations (Figure 2) of $\mathrm{H}_{3}-16 / \mathrm{C}-15, \mathrm{H}_{2}-14 / \mathrm{C}-15$ ( $\left.\delta_{\mathrm{C}} 208.6, \mathrm{qC}\right), \mathrm{H}_{2}-14 / \mathrm{C}-13, \mathrm{H}_{3}-17 / \mathrm{C}-13$ ( $\delta_{\mathrm{C}} 44.4$, $\mathrm{CH})$, and $\mathrm{H}_{3}-17 / \mathrm{C}-14\left(\delta_{\mathrm{C}} 47.0, \mathrm{CH}_{2}\right)$ secured the assignment of this alkyl side chain. The attachment of this alkyl moiety to $N-3$ was secured from the HMBC correlation from $\mathrm{H}-13$ to C-4, completing the assignment of compound 3 (Figures 1 and 2) as (Z)-5-(4-hydroxybenzylidene)-3-(4-oxopentan-2-yl) imidazolidine-2,4-dione. To the best of our knowledge, compound $\mathbf{3}$ is reported here for the first time from a natural source and is considered as a new compound. The generic name hemimycalin B was given to 3 .

Table 3. NMR data and HMBC correlations of compound 3 (DMSO- $d_{6}$ ).

\begin{tabular}{cccc}
\hline Position & $\boldsymbol{\delta}_{\mathbf{C}}$ & $\boldsymbol{\delta}_{\mathbf{H}}(\mathbf{m}, \boldsymbol{J}$ in $\mathbf{H z})$ & $\mathbf{H M B C}^{\mathbf{a}}$ \\
\hline 2 & $156.6, \mathrm{qC}$ & & $\mathrm{H}_{3}-13$ \\
4 & $166.2, \mathrm{qC}$ & & $\mathrm{H}-6, \mathrm{H}-13$ \\
5 & $125.7, \mathrm{qC}$ & & $\mathrm{H}-6$ \\
6 & $112.9, \mathrm{CH}$ & $6.52(\mathrm{~s})$ & $\mathrm{H}-12$ \\
7 & $125.0, \mathrm{qC}$ & & $\mathrm{H}-6, \mathrm{H}-9, \mathrm{H}-11$ \\
8 & $132.2, \mathrm{CH}$ & $7.33(\mathrm{~d}, 8.4)$ & $\mathrm{H}-6$ \\
9 & $117.0, \mathrm{CH}$ & $6.83(\mathrm{~d}, 8.4)$ & \\
10 & $159.9, \mathrm{qC}$ & & $\mathrm{H}-8, \mathrm{H}-9, \mathrm{H}-11, \mathrm{H}-12$ \\
11 & $117.0, \mathrm{CH}$ & $6.83(\mathrm{~d}, 8.4)$ & \\
12 & $132.2, \mathrm{CH}$ & $7.33(\mathrm{~d}, 8.4)$ & $\mathrm{H}_{3}-17$ \\
13 & $44.4, \mathrm{CH}$ & $4.64(\mathrm{~m})$ & $\mathrm{H}_{3}-16, \mathrm{H}_{3}-17$ \\
14 & $47.0, \mathrm{CH}_{2}$ & $3.35^{\mathrm{b}}$ & \\
\hline
\end{tabular}


Table 3. Cont.

\begin{tabular}{cccc}
\hline 15 & $208.6, \mathrm{qC}$ & & $\mathrm{H}_{2}-14, \mathrm{H}_{3}-16$ \\
16 & $29.9, \mathrm{CH}_{3}$ & $2.12(\mathrm{~s})$ & $\mathrm{H}_{3}-15$ \\
17 & $18.7, \mathrm{CH}_{3}$ & $1.36(\mathrm{~d}, 7.2)$ & \\
$\mathrm{N} H$ & & 10.47 (br hump) & \\
\hline
\end{tabular}

${ }^{a} \mathrm{HMBC}$ correlations are from proton(s) stated to the indicated carbons; ${ }^{\mathrm{b}}$ Overlapped with the $\mathrm{H}_{2} \mathrm{O}$ signal of the solvent.

\subsection{Biological Activities of the Isolated Compounds}

Compounds 1-3 were evaluated for their antiproliferative activity against the human cervical carcinoma HeLa cell line as well as for their antimicrobial activity against E. coli, S. aureus, and C. albicans. In the antiproliferative activity evaluation of the HeLa cells (Table 4), compound $\mathbf{1}$ showed moderate antiproliferative activity against HeLa cells with $\mathrm{IC}_{50}$ values of $28.3 \mu \mathrm{g} / \mathrm{mL}$. The other compounds were weakly active with $\mathrm{IC}_{50}>50 \mu \mathrm{g} / \mathrm{mL}$. In the antimicrobial screen, compounds 1-3 displayed good activity against $E$. coli with inhibition zones of 18,10 , and $20 \mathrm{~mm}$, respectively, while these compounds showed inhibition zones of 22, 14, and $20 \mathrm{~mm}$ against $C$. albicans. In addition, the compounds were inactive against $S$. aureus (Table 4).

Table 4. Antiproliferative and antimicrobial activities of compounds 1-3.

\begin{tabular}{|c|c|c|c|c|}
\hline \multirow[t]{2}{*}{ Compound } & \multirow{2}{*}{$\begin{array}{c}\begin{array}{c}\text { Antiproliferation } \\
\text { Activity }\left(\mathbf{I C}_{\mathbf{5 0}}, \boldsymbol{\mu g} / \mathbf{m L}\right)\end{array} \\
\text { HeLa Cell }\end{array}$} & \multicolumn{3}{|c|}{$\begin{array}{c}\text { Antimicrobial Activity } \\
\text { Inhibition Zone }(\mathrm{mm}) \text { at } 100 \mu \mathrm{g} / \mathrm{disc}\end{array}$} \\
\hline & & S. aureus & E. coli & C. albicans \\
\hline Compound 1 & 28.3 & NI & 18 & 22 \\
\hline Compound 2 & $>50$ & NI & 10 & 14 \\
\hline Compound $\mathbf{3}$ & $>50$ & NI & 20 & 20 \\
\hline Paclitaxel $^{\mathrm{a}}$ & 0.0014 & - & - & - \\
\hline Ciprofloxacin ${ }^{b}$ & - & 22 & 30 & - \\
\hline Ketoconazole $^{\mathrm{c}}$ & - & - & - & 30 \\
\hline
\end{tabular}

${ }^{a}$ positive cytotoxic control; ${ }^{b}$ positive antibacterial control $(5 \mu \mathrm{g} / \mathrm{disc}) ;{ }^{\mathrm{c}}$ positive antifungal control $(50 \mu \mathrm{g} / \mathrm{disc})$; NI $=$ No inhibition.

\section{Experimental Section}

\subsection{General Experimental Procedures}

IR spectra were measured on a Shimadzu Infrared-400 spectrophotometer (Shimadzu, Kyoto, Japan). Positive mode HRESIMS data were obtained on a Finnigan MAT-312 spectrometer (ThermoFinnigan GmbH, Tokyo, Japan). NMR spectra were obtained in DMSO- $d_{6}$ on Bruker Avance 600 spectrometer at $600 \mathrm{MHz}$ for ${ }^{1} \mathrm{H}$ NMR and $150 \mathrm{MHz}$ for ${ }^{13} \mathrm{C}$ NMR. NMR chemical shifts are expressed in parts per million (ppm) referenced to residual DMSO- $d_{6}$ solvent signals $\left(\delta_{\mathrm{H}} 2.49\right.$ for ${ }^{1} \mathrm{H}$ and $\delta_{\mathrm{C}} 39.54$ for ${ }^{13} \mathrm{C}$ ). For column chromatography, silica gel (70-230 mesh, Merck, Darmstadt, Germany) was used. Pre-coated $\mathrm{SiO}_{2} 60 \mathrm{~F}_{254}$ plates (Merck, Darmstadt, Germany) were used for TLC. 
HPLC purification was performed using Prominence Shimadzu HPLC System (Shimadzu Corporation, Tokyo, Japan).

\subsection{Biological Materials}

The sponge was collected by hand off the Saudi Red Sea coast of Jazan (Ghurab, north side) (N 1706'38.0" E 42 $04^{\prime} 01.9^{\prime \prime}$ ) at depths ranging from 10 to $17 \mathrm{~m}$ in May 2013. The sponge (Figure 3) forms an encrusting soft mass of about $1-3 \mathrm{~cm}$ thick, covering rocks or dead corals. The outer color is deep bluish with a greenish-yellow interior. The sponge is very soft and easy to cut. The blue surface color is caused by a concentrated pigmented surface layer approximately $150 \mu \mathrm{m}$ in thickness, which fades to a light beige color on preservation. The skeleton is plumose consisting of parallel loose bundles of thin spicules running from the substratum upwards through the sponge and fanning out at the surface. In between there are many loose spicules. Bundles have a diameter of 30-50 $\mu \mathrm{m}$ and contain 12-20 spicules in cross-section. Siliceous spicules are straight and thin, either strongyles (rounded at both ends) or styles (one end pointed), but otherwise similar in shape and size, ranging from 210-250 $\times 2-4 \mu \mathrm{m}$. These characters conform to the description of the type specimen of Hemimycale arabica, with which the present specimen has been compared. A voucher specimen is kept in the collections of the Naturalis Biodiversity Center at Leiden, The Netherlands, registration number ZMA Por. 16634. Another voucher specimen was deposited in the Red Sea Invertebrates Collection of the Department of Natural Products, Faculty of Pharmacy at King Abdulaziz University, under the code number DY-21. The sponge materials were kept frozen at $-20^{\circ} \mathrm{C}$ until processed.

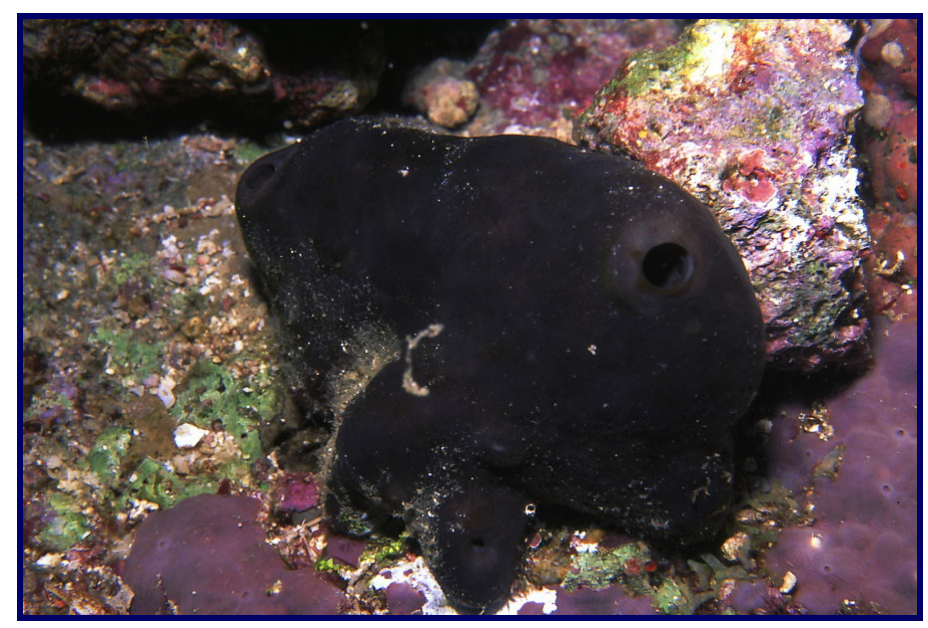

Figure 3. Underwater photograph of the Red Sea sponge Hemimycale arabica.

\subsection{Purification of Compounds $\mathbf{1}-\mathbf{3}$}

The frozen sponge materials $(0.78 \mathrm{~kg})$ were cut into small pieces and were extracted with a mixture of $\mathrm{CH}_{2} \mathrm{Cl}_{2} / \mathrm{MeOH}(1: 1)$. The crude extract was partitioned between in $60 \% \mathrm{MeOH}: \mathrm{H}_{2} \mathrm{O}(500 \mathrm{~mL})$ and $\mathrm{CH}_{2} \mathrm{Cl}_{2}(3 \times 500 \mathrm{~mL})$. The antimicrobial $\mathrm{CH}_{2} \mathrm{Cl}_{2}$ extract $(1.5 \mathrm{~g})$ was subjected to a flash silica gel column eluted with $n$-hexane- $\mathrm{CH}_{2} \mathrm{Cl}_{2}-\mathrm{MeOH}$ gradients to give 11 fractions. All fractions were subjected to the evaluation of their antimicrobial activities. Based on the antimicrobial results, fraction 9 , which was eluted with $20 \% \mathrm{MeOH}$ in $\mathrm{CH}_{2} \mathrm{Cl}_{2}$, was the most active among the tested fractions. Thus, 
this fraction (125 mg) was subjected to HPLC purification on a semipreparative HPLC column (RP18, $5 \mu \mathrm{m}$, ARII Cosmosil, $250 \times 10 \mathrm{~mm}$, Waters ) using $25 \%$ acetonitrile in water as an eluting solvent with a flow rate of $2 \mathrm{~mL} / \mathrm{min}$ and a detection at $220 \mathrm{~nm}$ to give compounds 1 (45 mg), 2 (11 mg), and 3 (24 mg).

\subsection{Spectroscopic Data of Compounds $1-3$}

(Z)-5-(4-Hydroxybenzylidene) imidazolidine-2,4-dione (1). Yellow amorphous solid; IR $\gamma_{\max }$ (film) 3385, 1720, 1646, $1593 \mathrm{~cm}^{-1}$; NMR data: see Table 1; HRESIMS m/z 227.0435 (calcd for $\left.\mathrm{C}_{10} \mathrm{H}_{8} \mathrm{~N}_{2} \mathrm{O}_{3} \mathrm{Na}[\mathrm{M}+\mathrm{Na}]^{+}, 227.0433\right)$.

Hemimycalin $A$ (2). Yellow amorphous solid; IR $\gamma_{\max }$ (film) 3374, 1723, 1645, $1592 \mathrm{~cm}^{-1}$; NMR data: see Table 1; HRESIMS $m / z 312.0961$ (calcd for $\mathrm{C}_{14} \mathrm{H}_{15} \mathrm{~N}_{3} \mathrm{O}_{4} \mathrm{Na}[\mathrm{M}+\mathrm{Na}]^{+}, 312.0960$ ).

Hemimycalin $B$ (3). Yellow amorphous solid; $[\alpha]_{\mathrm{D}}^{20}-12$ (c $\left.0.1 \mathrm{MeOH}\right)$; IR $\gamma_{\max }$ (film) 3378, 1724, 1643, $1590 \mathrm{~cm}^{-1}$; NMR data: see Table 1; HRESIMS $m / z 311.1009$ (calcd for $\mathrm{C}_{15} \mathrm{H}_{16} \mathrm{~N}_{2} \mathrm{O}_{4} \mathrm{Na}[\mathrm{M}+\mathrm{Na}]^{+}$, 311.1008 .

\subsection{Biological Evaluation of Compounds 1-3}

\subsubsection{Determination of the Antimicrobial Activities Using the Disc Diffusion Assay}

The in vitro antimicrobial activity was evaluated using the disc diffusion method, as previously described [25]. Varieties of test microorganisms were used, including a Gram-positive bacterium (Staphylococcus aureus ATCC 25923), a Gram-negative bacterium (Escherichia coli ATCC 25922), and yeast (Candida albicans ATCC 14053). The adjusted inoculum of each microorganism, equivalent to a turbidity of $0.5 \mathrm{McFarland}$ standards, was streaked separately using sterile swabs over the surface of Muller-Hinton agar plates. Sterile filter paper discs (6 mm diameter) were impregnated with $100 \mu \mathrm{g}$ of each compound and applied to the inoculated plates. The plates were incubated at $37{ }^{\circ} \mathrm{C}$ for $24 \mathrm{~h}$. Solvent control discs were used to determine any solvent effect. Ciprofloxacin $(5 \mu \mathrm{g} / \mathrm{disc})$ was used as an antibacterial standard, while ketoconazole ( $50 \mu \mathrm{g} / \mathrm{disc})$ was used as an antifungal standard. The activity of each compound was determined by measuring the diameter of the inhibition zone in mm. The technique was performed in duplicate, and the mean diameter of each inhibition zone was recorded.

\subsubsection{Evaluation of Antiproliferative and Cytotoxic Activities against HeLa Cells}

The effects of the compounds $\mathbf{1}-\mathbf{3}$ on HeLa cell proliferation and cytotoxicity were evaluated using the sulforhodamine B (SRB) assay [26-28]. HeLa cells were grown in Basal Medium Eagle (BME) containing Earle's salts, $10 \% \mathrm{FBS}$, and $50 \mu \mathrm{g} / \mathrm{mL}$ gentamycin sulfate. Cells were plated at a density of 2500 cells per well in a 96-well plate and allowed to adhere and grow for $24 \mathrm{~h}$ before compounds were added. The compounds were solubilized in DMSO and added to a final DMSO concentration of $1 \%$ in both test wells and vehicle controls. The cells were incubated with compounds or vehicle for an additional $48 \mathrm{~h}$. The $\mathrm{IC}_{50}$, the concentrations required to cause a 50\% inhibition of cell proliferation, was calculated from the log dose response curves. The values represent the average of 3-4 independent experiments, each conducted in triplicate \pm SEM. Cytotoxicity was determined by a cell density lower than that measured at the time of drug addition. Paclitaxel was used as a positive control. 


\section{Conclusions}

Investigation of the antimicrobial fraction of the organic extract of the Red Sea sponge Hemimycale arabica yielded three hydantoin alkaloids (1-3), including two new ones, hemimycalins A and B ( 2 and 3). Both 2 and $\mathbf{3}$ represent the first examples of natural $N$-alkylated hydantoin alkaloids from the sponge. Their structures were determined by extensive one-dimensional (1D) and two-dimensional (2D) NMR (COSY, multiplicity-edited HSQC, and HMBC) studies and high-resolution mass spectral determinations. Compound $\mathbf{1}$ displayed moderate cytotoxic activity against HeLa cells. In addition, the compounds displayed variable antimicrobial activities against different pathogens.

\section{Acknowledgments}

This work was supported by the Deanship of Scientific Research (DSR), King Abdulaziz University, Jeddah, under grant No. 166-575-D1435. The authors, therefore, gratefully acknowledge the DSR technical and financial support. We thank Susan Mooberry for the evaluation of the antiproliferation activity of the compounds. We also thank Rob van Soest for taxonomic identification of the sponge.

\section{Author Contributions}

D.T.A.Y. and L.A.S. designed the experiments; D.T.A.Y. collected the sponge specimen; D.T.A.Y. and L.A.S. performed the experiments; K.Z.A. performed the antimicrobial assays; L.A.S. and D.T.A.Y. and K.Z.A. analyzed the data; L.A.S. and D.T.A.Y. wrote and edited the manuscript.

\section{Conflicts of Interest}

The authors declare no conflict of interest.

\section{References}

1. Newman, D.J.; Cragg, G.M. Marine natural products and related compounds in clinical and advanced preclinical trials. J. Nat. Prod. 2004, 67, 1216-1238.

2. Blunt, J.W.; Copp, B.R.; Keyzers, R.A.; Munro, M.H.; Prinsep, M.R. Marine natural products. Nat. Prod. Rep. 2015, 32, 116-211

3. Ebada, S.S.; Proksch, P. The Chemistry of Marine Sponges. In Handbook of Marine Natural Products; Fattorusso, E., Gerwick, W.H., Taglialatela-Scafati, O., Eds.; Springer: New York, NY, USA, 2012; Volume 1, pp. 191-293.

4. Van Soest, R.W.M.; Boury-Esnault, N.; Vacelet, J.; Dohrmann, M.; Epenbeck, D.; de Voogd, N.J.; Santodomingo, N.; Vanhoorne, B.; Kelly, M.; Hooper, J.N.A. Global Diversity of Sponges (Porifera). PLoS ONE 2012, 7, e35105, doi:10.1371/journal.pone.0035105.

5. Laport, M.S.; Santos, O.C.S.; Muricy G. Marine sponges: Potential sources of new antimicrobial drugs. Curr. Pharm. Biotechnol. 2009, 10, 86-105. 
6. Mayer, A.M.S.; Glaser, K.B.; Cuevas, C.; Jacobs, R.S.; Kem, W.; Little, R.D.; McIntosh, J. M.; Newman, D.J.; Potts, B.C.; Shuster, D.E. The odyssey of marine pharmaceuticals: A current pipeline perspective. Trends Pharmacol. Sci. 2010, 31, 255-265

7. Ohtani, I.; Kusumi, T.; Kakisawa, H.; Kashman, Y.; Hirsh, S. Structure and chemical properties of ptilomycalin A. J. Am. Chem. Soc. 1992, 114, 8472-8479.

8. Kashman, Y.; Hirsh, S.; McConnell, O.J.; Ohtani, I.; Kusumi, T.; Kakisawa, H. Ptilomycalin A: A novel polycyclic guanidine alkaloid of marine origin. J. Am. Chem. Soc. 1989, 111, 8925-8926.

9. Williams, D.A.; Lemke, T.L. (Eds.) Foye's Principles of Medicinal Chemistry, 5th ed.; Lippincott Williams \& Wilkins: New York, NY, USA, 2002.

10. Kleemann, A.; Engel, J.; Kutscher, B.; Reichert, D. Pharmaceutical Substances: Synthesis, Patents, Applications, 4th ed.; Thieme Medical: Leipzig, Germany, 2001.

11. Malawska, B. New anticonvulsant agents. Curr. Topics Med. Chem. 2005, 5, 69-85.

12. Byrtus, H.; Obniska, J.; Czopek, A.; Kaminski, K.; Pawlowski, M. Synthesis and anticonvulsant activity of new N-Mannich bases derived from 5-cyclopropyl-5-phenyl- and 5-cyclopropyl-5(4-chlorophenyl)-imidazolidine-2,4-diones. Bioorg. Med. Chem. 2011, 19, 6149-6156.

13. Fiallo, M.M.L.; Kozlowski, H.; Garnier-Suillerot, A. Mitomycin antitumor compounds. Part 1. CD studies on their molecular structure. Eur. J. Pharm. Sci. 2001, 12, 487-494.

14. Gregoriou, M.; Noble, M.E.M.; Watson, K.A.; Garman, E.F.; Krulle, T.M.; Delafuente, C.; Fleet, G.W.J.; Oikonomakos, N.G.; Johnson, L.N. The structure of a glycogen phosphorylase glucopyranose spirohydantoin complex at 1.8 angstrom resolution and $100 \mathrm{k}$ - The role of the water structure and its contribution to binding. Protein Sci. 1998, 7, 915-927.

15. Shiozaki, M. Syntheses of hydantocidin and C-2 thioxohydantocidin. Carbohyd. Res. 2002, 337, 2077-2088.

16. Khanfar, M.A.; Hill, R.A.; Kaddoumi, A.; El Sayed, K.A. Discovery of novel GSK-3 beta inhibitors with potent in vitro and in vivo activities and excellent brain permeability using combined ligand- and structure-based virtual screening. J. Med. Chem. 2010, 53, 8534-8545.

17. Mudit, M.; Khanfar, M.A.; Muralidharan, A.; Thomas, S.; Shah, G.V.; van Soest, R.W.; El Sayed, K.A. Discovery, design, and synthesis of anti-metastatic lead phenylmethylene hydantoins inspired by marine natural products. Bioorg. Med. Chem. 2009, 17, 1731-1738.

18. Khanfar, M.A.; Abu Asal, B.; Mudit, M.; Kaddoumi, A.; El Sayed, K.A. The marine natural-derived inhibitors of glycogen synthase kinase- $3 \beta$ phenylmethylene hydantoins: In vitro and in vivo activities and pharmacophore modeling. Bioorg. Med. Chem. 2009, 17, 6032-6039.

19. Tan, S.; Ang, K.; Jayachandran, H.; Fong, Y. Substituent effects in ${ }^{1} \mathrm{H}$ and ${ }^{13} \mathrm{C}$ nuclear magnetic resonance correlations of chemical shifts in para-substituted 5-arylmethylenehydantoins. $J$. Chem. Soc. Perkin Trans. 1987, 2, 1043-1045.

20. Brastianos, H.C.; Vottero, E.; Patrick, B.O.; van Soest, R.; Matainaho, T.; Mauk, G.; Andersen, R.J. Exiguamine A, an indoleamine-2,3-dioxygenase (IDO) inhibitor isolated from the marine sponge Neopetrosia exigua. J. Am. Chem. Soc. 2006, 128, 16046-16047.

21. Balansa, W.; Islam, R.; Gilbert, D.F.; Fontaine, F.; Xiao, X.; Zhang, H. Piggott, A.M.; Lynch, J.W.; Capon, R.J. Australian marine sponge alkaloids as a new class of glycine-gated chloride channel receptor modulator. Bioorg. Med. Chem. 2013, 21, 4420-4425. 
22. Wang, Q.; Tang, X.; Luo, X.; de Voogd, N.J.; Li, P.; Li, G. (+)- and (-)-Spiroreticulatine, a pair of unusual spiro bisheterocyclic quinoline-imidazole alkaloids from the South China Sea sponge Fascaplysinopsis reticulata. Org. Lett. 2015, 17, 3458-3461.

23. Preecha Phuwapraisirisan, P.; Shigeki Matsunaga, S.; van Soest, R.W.M.; Fusetani, N. Isolation of a new mycalolide from the marine sponge Mycale izuensis. J. Nat. Prod. 2002, 65, 942-943.

24. Tsukamoto, S.; Keiichirou Koimaru, K.; Ohta, T. Secomycalolide A: A new proteasome inhibitor isolated from a marine sponge of the genus Mycale. Mar. Drugs 2005, 3, 29-35.

25. Kiehlbauch, J.A.; Hannett, G.E.; Salfinger, M.; Archinal, W.; Monserrat, C.; Carlyn, C. Use of the national committee for clinical laboratory standards guidelines for disk diffusion susceptibility testing in New York state laboratories. J. Clin. Microbiol. 2000, 38, 3341-3348.

26. Boyd, M.R.; Paull, K.D. Some practical considerations and applications of the National Cancer Institute in vitro anticancer discovery screen. Drug Dev. Res. 1995, 34, 91-109.

27. Skehan, P.; Storeng, R.; Scudiero, D.; Monks, A.; McMahon, J.; Vistica, D.; Warren, J.T.; Bokesch, H.; Kenney, S.; Boyd, M.R. New colorimetric cytotoxicity assay for anticancer-drug screening. J. Natl. Cancer Inst. 1990, 82, 1107-1112.

28. Risinger, A.L.; Jackson. E.M.; Polin, L.A.; Helms, G.L.; LeBoeuf, D.A.; Joe, P.A.; Hopper-Borge, E.; Ludueña, R.F.; Kruh, G.D.; Mooberry, S.L. The taccalonolides: Microtubule stabilizers that circumvent clinically relevant taxane resistance mechanisms. Cancer Res. 2008, 68, 8881-8888.

(C) 2015 by the authors; licensee MDPI, Basel, Switzerland. This article is an open access article distributed under the terms and conditions of the Creative Commons Attribution license (http://creativecommons.org/licenses/by/4.0/). 